Research, part of a Special Feature on Ecological Restoration in Northern Regions

\title{
Using Short-Term Monitoring Data to Achieve Goals in a Large-Scale Restoration
}

\author{
Dagmar Hagen $^{l}$ and Marianne Evju ${ }^{l}$
}

\begin{abstract}
To evaluate the outcome of restoration projects, an overall goal, reformulated to specific subgoals or targets, must be explicit and translated into scientifically measurable ecological attributes. Monitoring ecological attributes is necessary to assess restoration progress. Data from long-term monitoring are rarely available when restoration interventions are planned and implemented. In this study, we show how short-term monitoring data are incorporated into the planning of the large-scale restoration of a former military training area: the largest restoration project approved in Norway, covering more than $165 \mathrm{~km}^{2}$ and intended to enhance nature conservation.
\end{abstract}

A pilot project was initiated in 2002 that removed $1.2 \mathrm{~km}$ of roads and tested three restoration treatments to facilitate vegetation development: stirred topsoil (C, control), fertilizer added to the stirred topsoil (F), and fertilizer and commercial grass seeds added to the stirred topsoil (FS). Vegetation turfs were transplanted in all treatments. A monitoring program was established, and three ecological attributes linked to the specific targets for vegetation development (vegetation cover, species richness, and presence of non-native species) were sampled at $2 \mathrm{yr}$ and $7 \mathrm{yr}$ after the intervention.

We discuss pilot project results in relation to the temporal scale and to the type of intervention of the restoration treatments (introduction of non-native seeds and nutrient addition) in an ecosystem with slow nutrient turnover. We consider the implications of the short-term data for the large-scale restoration and describe the cooperation between developers, research ecologists, and contractors, illustrating how adaptive management is relevant to large-scale restoration projects.

Key Words: adaptive management; alpine; ecological attributes; restoration success; restoration target; species richness; vegetation cover

\section{INTRODUCTION}

During the past decade, ecological restoration has been approved both politically and scientifically as a tool to assist the recovery of degraded land (MEA 2005, Comín 2010) and the delivery of ecosystem services (Rey Benayas et al. 2009, Bullock et al. 2011, Suding 2011). Ecological theory is an important basis for the science of restoration ecology (Palmer et al. 2004, Young et al. 2005), but there is also a growing understanding of an integrated approach including a socioeconomic framework to meet the society's needs for sound restoration projects (Hagen 2003, SER 2004, Clewell and Aronson 2007).

The evaluation of a restoration project's outcome should always be an integrated part of restoration projects (Hobbs and Norton 1996, Tischew et al. 2010). This will allow for correction if the development is on the wrong track, ecologically or socially, justify the use of public or private money, and collect valuable information for future restoration activities (Suding 2011).

All restoration projects should have an overall goal. Goals can be rather general and unspecific while still functioning as guiding light and motivation for the project and its involved partners and communicated to stakeholders and other relevant groups (e.g., Hekluskogar at Iceland; Aradóttir 2007). For evaluating an outcome of restoration, a number of specific subgoals, or targets, must be formulated. Such targets form the basis for planning and implementation of the project. A restoration project will benefit from an evident link between an overall, paramount goal and specific, measurable targets, in particular in large and complicated projects (Grant 2006).

An ecosystem's properties, e.g., its species diversity, potential for self-sustainability, landscape integrity, and internal processes, often form the basis for formulating targets and criteria for evaluation (SER 2004, Ruiz-Jaen and Aide 2005a). However, many ecosystem properties and corresponding targets can be difficult to measure. Hence, it is essential that targets are translated into ecological attributes that are scientifically measurable for a clear and objective evaluation of a restoration's outcome (Hildebrand et al. 2005, Ruiz-Jaen and Aide 2005b, Zedler 2007).

Regular monitoring of an area under restoration is necessary to assess the restoration's progress. Unfortunately, data from long-term monitoring are only rarely available when restoration interventions are being planned and implemented. In some fortunate instances, data from short-term monitoring represent the best available information. A sensible management strategy utilizes these short-term data optimally and accommodates for adjusting methods and procedures if 
further monitoring data indicate a need (Howell et al. 2012). This type of strategy corresponds with adaptive management (Holling 1978) and uses the best available knowledge including local knowledge, formulating goals, embracing uncertainty, and evaluation procedures as its essential components (Gardner 2010, Keith et al. 2011).

Natural recovery from human degradation in alpine areas is limited by abiotic factors such as low temperatures, a short growing season, and low water and nutrient availability (Ebersole 2002, Willard et al. 2007), factors that reduce these systems' resilience, i.e., the ability to return to the original state following a disturbance (Pimm 1984). Physical interventions and vegetation treatment can be used to assist the natural recovery, increasing the resilience and vegetation cover development (Skrindo and Økland 2002, Whisenant 2002). A number of procedures are available for this purpose and are each influenced in different ways by ecological, monetary, aesthetic, logistic, and speed considerations (Perrow and Davy 2002). In alpine areas, three main groups of techniques have traditionally been applied: (1) remediation of soil and terrain, (2) adding nutrients, and (3) seeding or planting (Urbanska and Chambers 2002, Krautzer and Wittmann 2006).

We use the restoration of a former military training area in alpine central Norway as a case study to illustrate the link between an overall goal, ecological targets, measurable attributes, and restoration intervention levels (Fig. 1) and illustrate how short-term monitoring data on vegetation recovery are used in the planning and implementation of the ongoing restoration activities in the area.

Fig. 1. The link between the overall goal, specific targets, ecological attributes, and the vegetation treatments in the restoration of a former military training area. The comprehensive overall goal is broken down into a number of specific, ecological targets. Ecological attributes are measureable surrogates for each of the specific targets.

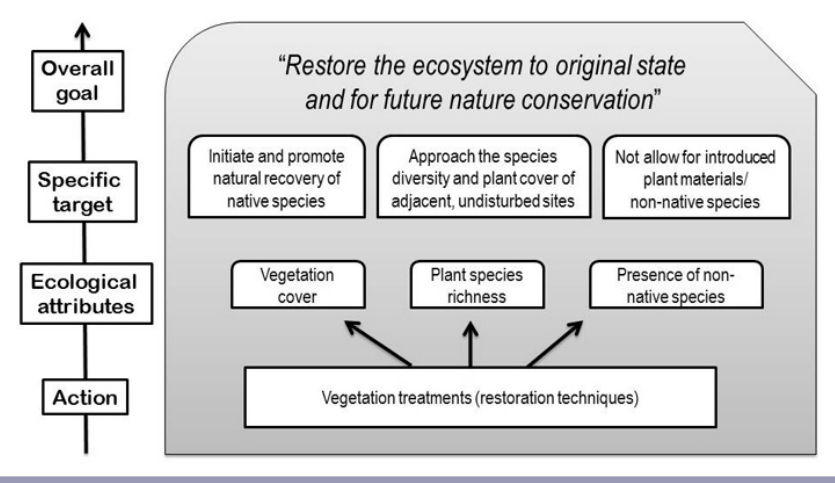

The overall goal of this project was to "reset the area for civilian use and to restore the ecosystem to its original state and for future nature conservation (National Park)" (Ministry of Defence 1998). A "Plan for Restoration" was formulated, dividing this comprehensive goal into a number of specific, ecological targets for the vegetation development (http:// www.forsvarsbygg.no/hjerkinn; Fig. 1). A pilot study tested three restoration treatments for facilitating vegetation recovery, and a monitoring program evaluated the effects on vegetation development as specified by three ecological attributes (Fig. 1). We (1) evaluated the effects of the restoration treatments on short-term vegetation development in terms of vegetation cover, plant species richness, and the presence of non-native species; and (2) elaborated how the ecological results are implemented in the running restoration of the area and can contribute to meeting the overall goal of the restoration project.

\section{METHODS}

\section{Study area}

The study area is the Hjerkinn firing range, a former military training area situated between 1000 and $1700 \mathrm{~m}$ above sea level (a.s.l.) in Dovrefjell, central Norway, surrounded by nature conservation areas (Fig. 2). The military activity started in 1923 and expanded extensively from the 1960s with the development of heavy infrastructure, such as military training facilities and a network of roads. It became the largest military area in South-Norway, covering $165 \mathrm{~km}^{2}$. The surrounding conservation areas hold populations of wild reindeer (Rangifer tarandus), wolverine (Gulo gulo), and arctic fox (Vulpes lagopus), and the Dovrefjell area is described as "the last nearly intact high-mountain ecosystem in Europe" by Norwegian management authorities (Directorate for Nature Management 2012).

Mean annual temperature (1997-2006) at the closest weather station (Fokstugu, $973 \mathrm{~m}$ a.s.l.) is $0.8^{\circ} \mathrm{C}$, with mean annual precipitation of $444 \mathrm{~mm}$ (Norwegian Meteorological Institute 2010). The bedrock is dominated by Precambrian metamorphosed rock covered by till (Norwegian Geological Survey 2011). The study sites are situated in dry and mediumdry alpine heath dominated by lichens, dwarf shrubs, and some grasses and herbs.

The Norwegian Parliament decided in 1999 to close down the firing range and restore the area to its natural state (Ministry of Defence 1998). This project is managed by the Norwegian Defense Estate Agency and represents the largest restoration project ever approved in Norway, including removal of more than 100 buildings, butts, gravel pits and other installations, and $90 \mathrm{~km}$ of roads. The project also involves removing undetonated explosives, foul matters, and other pollutants. 
Fig. 2. The study area in Hjerkinn firing range situated at the Dovrefjell mountain area, central Norway (red line), surrounded by protected areas (green color).

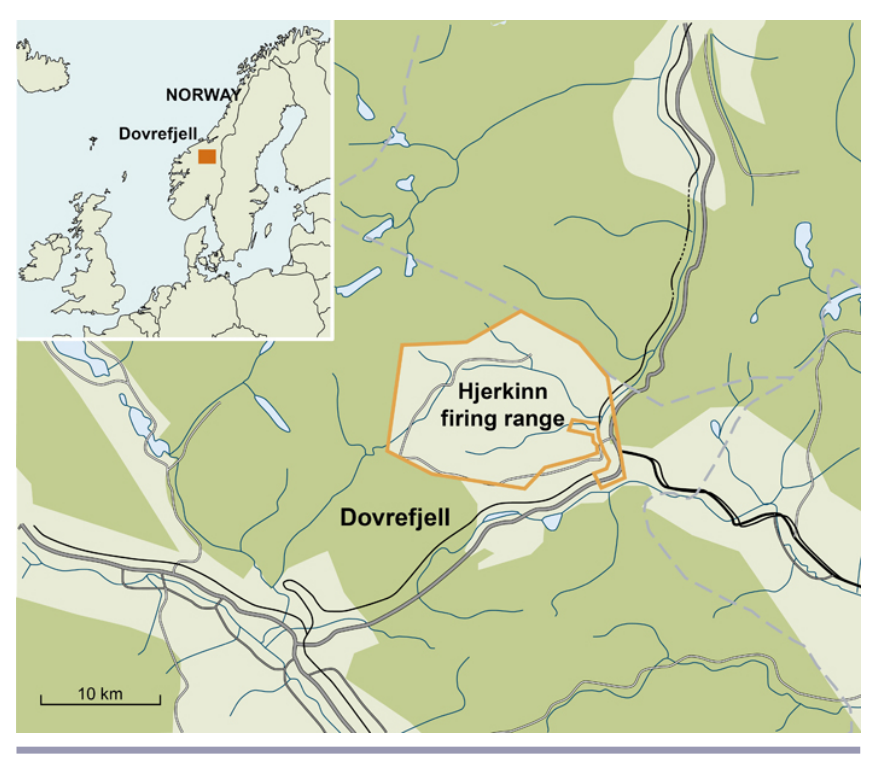

Three specific targets for vegetation development are formulated in the restoration project. The physical intervention and vegetation treatments should accomplish the following: (1) initiate and promote natural recovery of native species, (2) approach the species diversity and plant cover of adjacent, undisturbed sites, and (3) not allow for introduced plant materials/non-native species. These targets relate to the overall project goal, which is to restore the area for future wilderness and nature conservation.

A pilot project removing $1.2 \mathrm{~km}$ of roads began in 2002 and was designed to verify the safety and effectiveness of the technical and ecological methods as well as the economic calculations for the large-scale restoration. A monitoring program recorded the recovery of the vegetation following different treatments, using three ecological attributes to evaluate the effects of restoration treatments on vegetation development: vegetation cover, species richness, and abundance of non-native species.

The full large-scale ecological restoration and removal of technical infrastructure and roads started in 2008. Native seeds of Festuca ovina, a common pioneer species in the area, were propagated and made available for the large-scale restoration (Martinsen and Oskarsen 2010), although they were not ready for use in the 2002 pilot project.

\section{Study design of the pilot project}

The pilot project was established along three roads (total length of $1.2 \mathrm{~km}$ ) that were constructed during the $1960 \mathrm{~s}$ by adding crushed stone and gravel on top of undisturbed vegetation. In
August 2002, a shell-proof excavator removed the crushed stone down to the original terrain surface, and the original soil top layer was stirred down to $20 \mathrm{~cm}$ as the excavator grab lifted the compressed surface (Fig. 3).

Fig. 3. Pilot project design, with a road divided into blocks, each allocated to one treatment type, and plots located in blocks. Treatment 1 is control (C; stirred top-soil, no further treatment), 2 is fertilization treatment (F; $20 \mathrm{~g} / \mathrm{m} 2$ of granulated NKP-fertilizer added to the stirred top-soil), and 3 is fertilization and seeding treatment (FS; in addition to fertilizer $7 \mathrm{~g} / \mathrm{m} 2$ of commercial seeds of Festuca rubra were added to the stirred top-soil). Turfs of vegetation are transplanted into all treatments. Five permanent plots are placed randomly in each block.

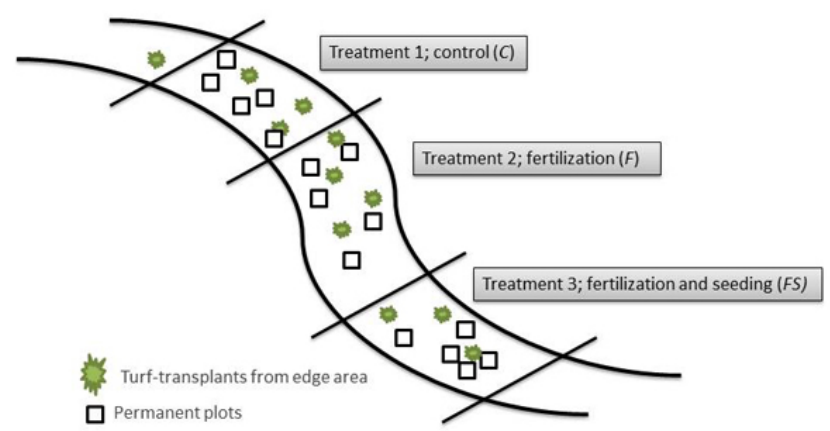

Three vegetation treatments were tested: (1) control $(C$; stirred topsoil, no further treatment), (2) fertilization ( $F ; 20 \mathrm{~g} / \mathrm{m}^{2}$ of granulated N-K-P fertilizer added to the stirred topsoil), and (3) fertilization and seeding (FS; both $20 \mathrm{~g} / \mathrm{m}^{2}$ fertilizer and 7 $\mathrm{g} / \mathrm{m}^{2}$ of commercial seeds of Festuca rubra were added to the stirred topsoil). Plots or turfs of vegetation act as seed sources, seed traps, or sources for vegetative regeneration (Aradóttir 2012). We therefore transplanted $\leq 1 \mathrm{~m}^{2}$ vegetation turfs from nearby road margins into all vegetation treatments, at a 5-10 $\mathrm{m}$ planting distance. We followed a strict protocol for collecting the turfs to avoid causing damage to the surrounding intact vegetation.

Each road was divided into three approximately $100 \mathrm{~m}$ long blocks, and the vegetation treatments were randomly allocated among the blocks in each road. To monitor vegetation development, 5 permanent plots $\left(0.5 \times 0.5 \mathrm{~m}^{2}\right)$ were established in each block, giving a total of 45 plots ( 5 plots per block, 3 blocks per road, 3 roads; Fig. 4). All road sections were situated in flat heath vegetation at about $1000 \mathrm{~m}$ a.s.l.

We recorded vegetation in the plots and measured distance to transplanted turfs in 2004 and 2009, 2 yr and 7 yr after the intervention and vegetation treatments. We recorded the abundance of vascular plants as presence/absence of each species in 16 subplots $\left(12.5 \times 12.5 \mathrm{~cm}^{2}\right)$ per plot. In addition, 
Fig. 4. Restoration of military access road (width of road is $5 \mathrm{~m}$ ) by removing added gravel and stone, stirring the original topsoil, and transplanting turfs from the road margins. Left: the road before restoration (2002). Right: the road three years after restoration (2005). The arrow indicates a fixed point for comparison between the pictures.

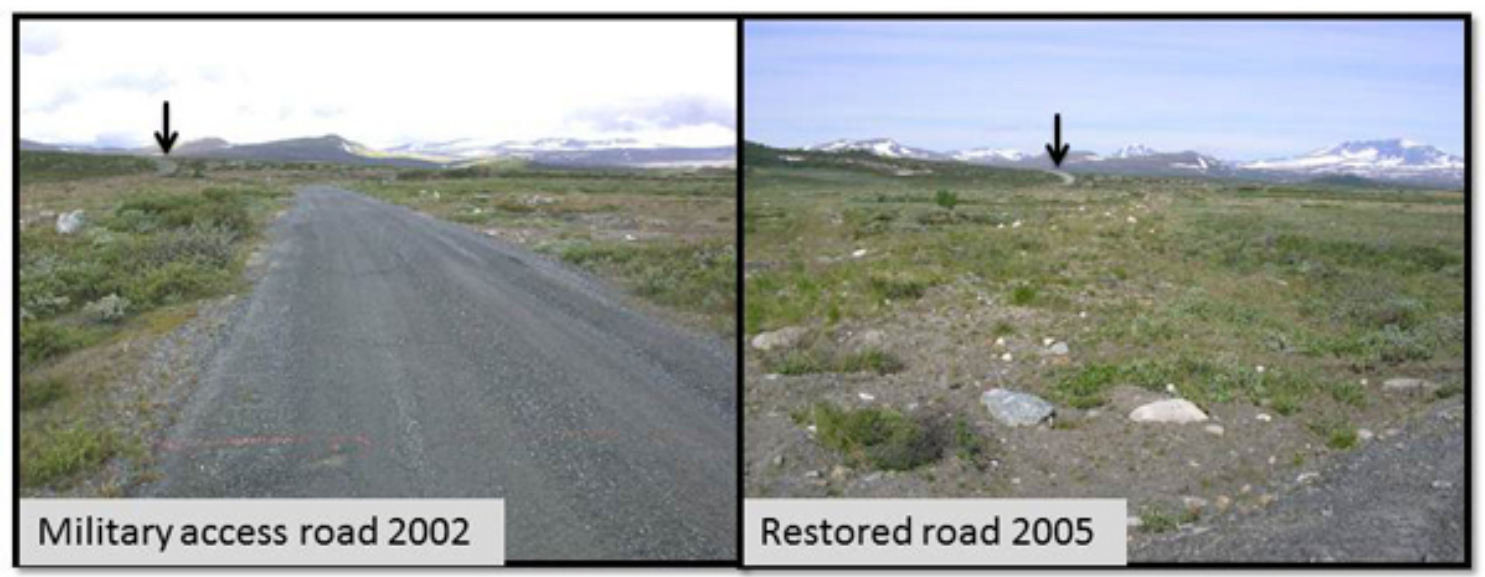

we recorded total vegetation cover, cover of dead organic matter, and cover of bare soil (\%). In the seeded plots, we recorded the percentage cover of F. rubra. Deschampsia cespitosa is a native species in the study area but is non-native in alpine heath vegetation. It is expanding into disturbed sites and is an invasive species in heath vegetation, and it is consequently not a wanted species in restored vegetation, i.e., not in accordance with the ecological targets (Fig. 1).

We used data collected previously from 32 plots in undisturbed vegetation close to the study site (Strømsæther 2006) to serve as reference data. These data described presence/absence and total vegetation cover only and did not include species abundances. Therefore, we chose not to incorporate these data in our statistical analyses but rather present them in the figures referred to as reference vegetation.

\section{Statistical analysis}

We used linear mixed-effect models (Pinheiro and Bates 2000) to evaluate the impact of vegetation treatments on (1) vegetation cover, (2) species richness, and (3) non-native species.

To incorporate the nested structure of the pilot study (blocks in roads, plots in blocks) and repeated measurements on the same plots, we included plot nested in block nested in road as random factors in the models. Fixed factors were the explanatory variables year (factor variable), treatment type (factor variable), and distance to nearest transplanted vegetation turf (continuous variable, $\log _{2}$ transformed), with all relevant interactions. We used Akaike information criterion (Crawley 2003) for model selection and present only the most parsimonious models. Data on vegetation cover were square- root transformed prior to analyses to reduce heteroscedasticity. Models with species richness were run with Poisson error distribution. All analyses were carried out with the software R (R Development Core Team 2011), packages lme4 (Bates and Maechler 2010) and nlme (Pinheiro et al. 2011). All figures show back-transformed values.

\section{RESULTS}

The model that fit vegetation cover best included year, treatment, and the interaction between them (Table 1a). The FS treatment resulted in higher vegetation cover than the $\mathrm{C}$ treatment, with $\mathrm{F}$ having intermediate values (Fig. 5a). Vegetation cover increased from 2004 to 2009, but more in the $\mathrm{C}$ treatment than in the FS treatment, reducing the difference in cover between treatments in 2009. There was no effect of distance to transplanted turfs on vegetation cover.

The model that fit species richness best included year, treatment, and the interaction between them, as well as distance to nearest transplant (Table 1b). Species richness was lowest in the FS treatment both in 2004 and 2009. Species richness increased from 2004 to 2009 in all treatments, but with a lower rate in the $\mathrm{F}$ treatment, giving relatively small differences in species richness between treatments in 2009 (Fig. 5b). There was an additional positive effect of closeness to transplants; species richness decreased with increasing distance.

Two graminoid species present in the plots were non-native in these vegetation types, the seeded $F$. rubra and $D$. cespitosa. F. rubra covered on average $41 \%$ of the plots with FS treatment in 2004 and $48 \%$ in 2009 (Fig. 5a), with no significant change in abundance over time $\left(F_{1,12}=0.594, P=0.456\right)$. The grass 
Table 1. Linear mixed-effect model results of a) vegetation cover (\%, square-root-transformed), b) species richness (modeled with Poisson distribution), and c) abundance (subplot frequency, square-root-transformed) of Deschampsia cespitosa as a function of time, treatment, and distance to transplanted vegetation turfs. Intercept refers to averages for the control treatment (C) in 2004. $\mathrm{C}=$ control/soil, $\mathrm{CF}=$ fertilizer, and CFS $=$ fertilizer and seeds. Parameter estimates of random effects (plot nested in block nested in road) are not shown.

\begin{tabular}{|c|c|c|c|c|c|}
\hline Variable & estimate & S.E. & df & $\mathrm{t}$ & $\mathrm{p}$ \\
\hline \multicolumn{6}{|l|}{ a) vegetation cover } \\
\hline Intercept & 2.846 & 0.721 & 40 & 3.948 & $<0.001$ \\
\hline F vs. C & 1.668 & 0.967 & 4 & 1.725 & 0.160 \\
\hline FS vs. C & 3.691 & 0.697 & 4 & 3.818 & $<0.001$ \\
\hline 2009 vs. 2004 & 3.042 & 0.432 & 40 & 7.048 & $<0.001$ \\
\hline$F \times 2009$ & -0.773 & 0.605 & 40 & -1.278 & 0.205 \\
\hline $\mathrm{FS} \times 2009$ & -2.097 & 0.610 & 40 & -3.435 & 0.001 \\
\hline \multicolumn{6}{|l|}{ b) species richness } \\
\hline Intercept & 1.206 & 0.201 & 40 & 5.988 & $<0.001$ \\
\hline F vs. C & 0.379 & 0.223 & 4 & 1.695 & 0.090 \\
\hline FS vs. C & -0.577 & 0.264 & 4 & -2.184 & 0.029 \\
\hline 2009 vs. 2004 & 0.980 & 0.156 & 40 & 6.271 & $<0.001$ \\
\hline $\log ^{2}$ (distance to transplant) & -0.064 & 0.023 & 40 & -2.830 & 0.005 \\
\hline$F \times 2009$ & -0.467 & 0.210 & 40 & -2.228 & 0.026 \\
\hline $\mathrm{FS} \times 2009$ & 0.386 & 0.258 & 40 & 1.495 & 0.135 \\
\hline \multicolumn{6}{|c|}{ c) Deschampsia cespitosa abundance } \\
\hline Intercept & 0.259 & 0.098 & 40 & 2.626 & 0.012 \\
\hline F vs. C & 0.225 & 0.139 & 4 & 1.617 & 0.181 \\
\hline FS vs. C & -0.242 & 0.139 & 4 & -1.737 & 0.157 \\
\hline 2009 vs. 2004 & 0.227 & 0.048 & 40 & 4.734 & $<0.001$ \\
\hline$F \times 2009$ & -0.034 & 0.067 & 40 & -0.507 & 0.615 \\
\hline $\mathrm{FS} \times 2009$ & -0.202 & 0.068 & 40 & -2.975 & 0.005 \\
\hline
\end{tabular}

D. cespitosa was present in 2004 in both the $\mathrm{C}$ and the $\mathrm{F}$ treatment plots, with highest abundance in the $\mathrm{F}$ treatment (Table 1c, Fig. 5c). The abundance of D. cespitosa increased from 2004 to 2009, although the abundance in the FS treatment remained low (significant treatment $\times$ year interaction; Table 1c). The visual landscape effect of removing the road was striking after $3 \mathrm{yr}$ (Fig. 3).

\section{DISCUSSION}

To achieve the overall goal in large or complex restoration projects, it is useful to formulate specific targets that are linked to measurable ecological attributes. Although the targets-toattributes hierarchy improves the evaluation of project process and restoration outcome (Fig. 1), it does assume a connection between the ecological attributes and the targets. We briefly discuss the effect of vegetation treatments on the ecological attributes. Table 2 gives a simplified summary of these results and what direct implications they have on the large-scale considerations. We elaborate on how these results are incorporated into the large-scale restoration project.

\section{Effects of vegetation treatments on the ecological attributes}

Slow nutrient cycling in alpine ecosystems causes a lack of available nutrients (Walker and del Moral 2003), and application of limiting resources is a commonly used approach in restoration (Whisenant 1999). Adding fertilizer can rapidly increase the vegetation cover. However, our results showed only a small, nonsignificant difference in vegetation cover between the fertilized plots and the control plots. Fertilizer treatments can favor the growth of nutrient-adapted species such as grasses and thereby displace or impede colonization by other species in the community (Densmore 1992, Smits et al. 2008, Moulton and Gough 2011). The presence in the fertilized plots of D. cespitosa, which does not occur in the undisturbed vegetation, can be interpreted as an early warning that this displacement is taking place. Although $D$. cespitosa is native to Norway and common in moderately disturbed mountain ecosystems, it is a strong competitor and non-native in alpine heath vegetation and therefore not desirable in the restoration scheme at Hjerkinn. Future monitoring data will be important for setting recommendations for the use of fertilizer for the restoration program.

Seeded species in revegetation projects are traditionally fastgrowing and nutrient-adapted grasses, providing a rapid development of vegetation cover. However, because these grasses are able to establish permanently and occupy space at the cost of native plant species (Rydgren et al. 2011), seeding can cause a reduction of species diversity compared to 
Table 2. Summary of the response of ecological attributes to the vegetation treatments after two (2004) and seven (2009) years, with links to specific targets and overall goal for restoration (see Fig. 1 for relationships between the levels). The consequences for large-scale interventions are briefly elaborated, see text for more details. Presence of non-natives includes both the seeded Festuca rubra and the Deschampsia cespitosa, which occurred naturally in other sites the area, but act as an invader in alpine heath vegetation. Links between ecological attributes and the specific targets are slightly, moderately, or strongly negative, $(-)$, - or -- , respectively, neutral (0) or slightly, moderately, or strongly positive, $(+),+$ or ++ , respectively.

\begin{tabular}{|c|c|c|c|c|c|c|c|c|}
\hline \multirow{3}{*}{$\begin{array}{l}\text { Action (pilot) } \\
\text { Vegetation treatment }\end{array}$} & \multicolumn{6}{|c|}{ Relationship between ecological attributes and specific targets } & \multirow{3}{*}{$\begin{array}{l}\text { Treatment assessment } \\
\text { Linking targets and } \\
\text { overall goal }\end{array}$} & \multirow{3}{*}{$\begin{array}{l}\text { Implications for the large } \\
\text { scale restoration } \\
\text { Present use }\end{array}$} \\
\hline & \multicolumn{2}{|c|}{ Vegetation cover } & \multicolumn{2}{|c|}{ Species richness } & \multicolumn{2}{|c|}{$\begin{array}{c}\text { Presence of non- } \\
\text { natives }\end{array}$} & & \\
\hline & 2004 & 2009 & 2004 & 2009 & 2004 & 2009 & & \\
\hline Stirred topsoil (C) & $(+)$ & + & $(+)$ & ++ & $(-)$ & $(-)$ & OK, but slow start. & Basic treatment. \\
\hline $\begin{array}{l}\text { Stirred topsoil \& } \\
\text { fertilization }(\mathrm{F})\end{array}$ & $(+)$ & + & + & ++ & - & - & $\begin{array}{l}\text { No additional positive } \\
\text { effect. }\end{array}$ & Not used yet. \\
\hline $\begin{array}{l}\text { Stirred topsoil, } \\
\text { fertilization, and } \\
\text { seeding (FS) }\end{array}$ & + & + & $(+)$ & ++ & -- & -- & $\begin{array}{l}\text { Quick development of } \\
\text { cover. Dominance of } \\
\text { seeded species. }\end{array}$ & $\begin{array}{l}\text { Seeding of native species } \\
\text { used in large sites. }\end{array}$ \\
\hline $\begin{array}{l}\text { Vegetation turf } \\
\text { transplants }\end{array}$ & 0 & 0 & + & + & not tested & not tested & $\begin{array}{l}\text { Positive effect on } \\
\text { species richness. }\end{array}$ & $\begin{array}{l}\text { Basic treatment in narrow } \\
\text { sites. }\end{array}$ \\
\hline
\end{tabular}

nonseeded sites (Densmore 1992, Holl 2002, Gretarsdóttir et al. 2004). In line with this, we found the fertilizer and seeding treatment to give a rapid development of a stable vegetation cover, and this vegetation cover was mainly constituted by the seeded species with lower species richness than the other treatments. Species richness generally increases community resilience through providing a greater variety of regrowth strategies following a disturbance event, i.e., higher response diversity (Walker et al. 1999, Elmqvist et al. 2003). Our results also indicate that seeding inhibits establishment of native plant species on a short-term basis.

Transplanting of vegetation turfs has been applied to improve vegetation recovery in disturbed alpine sites (Conlin and Ebersole 2001, Bay and Ebersole 2006). Using turfs introduces new plants, seeds, or vegetative units as a foundation for new vegetation (Aradóttir 2012), and at the same time, turfs can work as safe sites for establishment. We found that the proximity to transplanted turfs had no effect on vegetation cover but did increase species richness, independent of other treatments, indicating that the turfs function as seed sources. Because of small seedling size, high seedling mortality, and slow plant growth (Erschbamer et al. 2001, Forbis 2003), the short-term contribution of seedlings to vegetation cover could be expected to be small. However, at longer time scales, both the establishment and growth of seedlings and vegetative expansion from the turfs can increase vegetation cover. The results point to planting of turfs as a highly relevant restoration method in smaller disturbed sites when a relatively high supply of turfs can be supported, e.g., along roads with welldeveloped vegetation along the margins. Larger sites rarely have sufficient vegetation to provide enough turfs without causing considerable damage, in addition to likely having a greater distance to intact vegetation. Combination with other treatments must therefore be considered for restoration of vegetation at large sites.

\section{Linking ecological attributes and targets}

Reference sites that represent the goal ecosystem are useful for evaluating links between ecological attributes and formulated ecological targets (Ruiz-Jaen and Aide 2005a) and can partly compensate for the lack of long-term monitoring data. Our short-term monitoring data show low vegetation cover and high species richness compared with reference vegetation (Fig. 5), mainly due to high abundance of woody species and lichens in the reference sites. These species groups have slow inherent growth rates and low recovery rates (MacGillivray et al. 1995, Den Herder et al. 2003), although other studies have shown that cryptogam communities return faster to the "reference point" than vascular plant communities, at least under wet conditions (Rydgren et al. 2011). Because the pilot study plots are in an early successional phase, the species richness is high compared with the reference vegetation, with an anticipated reduction in the number of species per plot as the sizes of individual plants/ramets increase with time. Nevertheless, environmental factors like soil moisture and nutrient levels are likely to differ between disturbed and undisturbed alpine sites. Therefore, even latesuccessional vegetation will diverge from an undisturbed reference state (Odland and Munkejord 2008, Rydgren et al. 2011).

The effect of vegetation treatments on the measured ecological attributes (cf. Table 2, Fig. 1) could be expected to be context dependent because abiotic and biotic conditions vary among 
Fig. 5. Mean ( \pm SE) a) vegetation cover (\%), b) species richness, and c) abundance of Deschampsia cespitosa (recorded as subplot frequency in 16 subplots per plot) in 2004 and 2009 in the vegetation treatments and the undisturbed reference site. In a) dark grey bars in the FS treatment show means cover of the seeded Festuca rubra. $\mathrm{C}=$ control/soil, F $=$ fertilizer, and FS = fertilizer and seeds, reference is the undisturbed reference site.
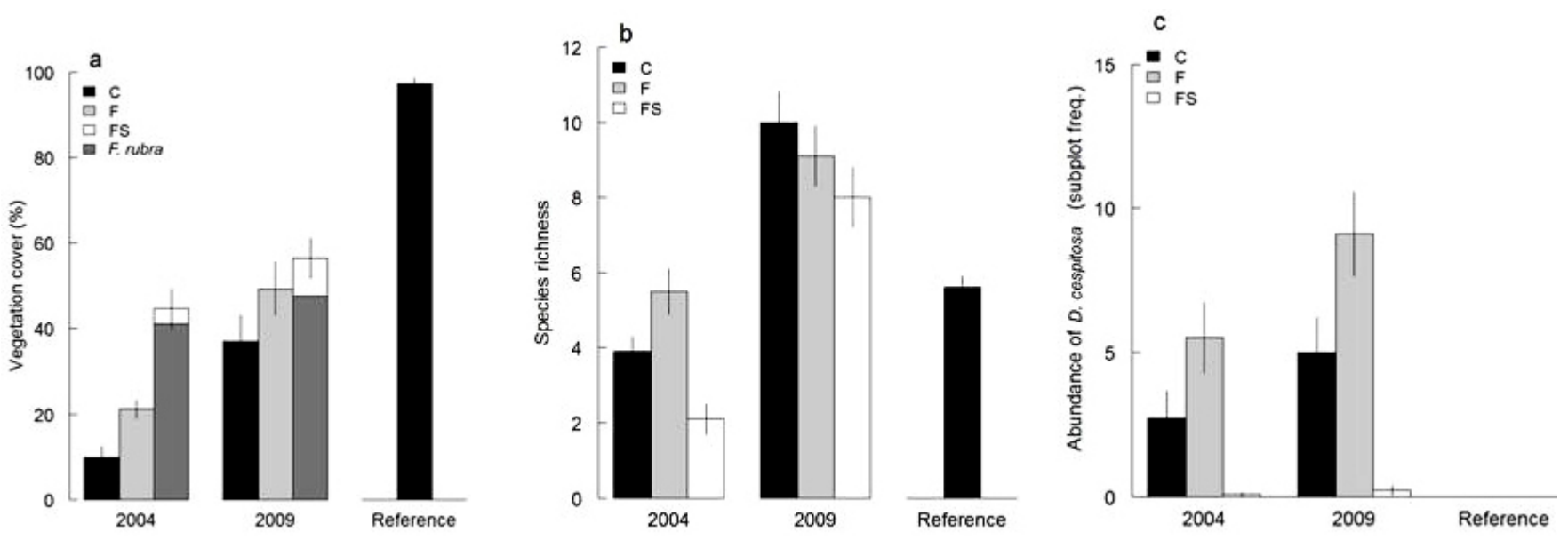

sites. Our short-term monitoring data showed a large increase in vegetation cover and number of species from 2004 to 2009 in the control treatment and suggest that the fertilizer and seed application are superfluous under the conditions provided in the monitoring sites. However, on steep slopes exposed to water or wind erosion, the quick establishment of a grass cover can be a wanted strategy to impede further degradation. Under such conditions, a vegetation cover will stabilize the soil, capture nutrients and water, and potentially provide safe sites for native species over the long term (Delach and Kimmerer 2002, Urbanska and Chambers 2002). The observed results from this pilot study or any other case study can partly be generalized, but links between the targets and the restoration interventions depend on the ecological and logistic relevance of the measured attributes (Table 2).

\section{Incorporating the ecological data into the restoration program}

The pilot project was intended to produce data to help guide the large-scale restoration at the Hjerkinn site. After $7 \mathrm{yr}$ of monitoring, we can evaluate the ecological and logistical relevance of these data.

Our data show that the vegetation development converges over time in the plots exposed to different vegetation treatments. Using a less costly and less complicated treatment, such as the stirred topsoil in combination with vegetation turfs, would therefore be a preferred strategy for such small and relatively flat sites (Table 2). Both rapid establishment of species and low abundance of non-natives are congruent with the project's specific targets. However, slow establishment of a vegetation cover can be a problem where there is a risk of erosion, like on steep slopes or in exposed and dry sites with sparse vegetation. In the large-scale restoration project, stirring of the topsoil has been applied as the basic treatment since 2008, based on the evaluation of the ecological data and because the sites restored so far mainly have been flat sites in low-alpine vegetation.

Fertilizer applications produce greater biomass in instances when some vegetation, vegetative units, or seeds are already present than in sites without a vegetation cover (Kelley and Epstein 2009). The fertilizer treatment has not been used in the continued large-scale restoration because so far no sites have had these characteristics. Continued monitoring will help detect whether the non-native competitive grass $D$. cespitosa establishes more rapidly in the fertilized sites and displaces other species.

The recent availability of seeds of the native $F$. ovina for the large-scale restoration provides interesting prospects. In the pilot study, the seeding treatment was most in conflict with the ecological targets of the project because of the total dominance of the introduced $F$. rubra. The seeding itself quickly produced a vegetation cover and might facilitate the establishment of a vegetation cover in exposed disturbed sites. Replacing seeds of an introduced species with native seeds is a better match for the project's ecological targets. Use of the propagated native seed has been proposed for two large sites where long distance to intact vegetation acting as a propagule source can hamper colonization of native heath vegetation. In addition, the availability of turfs for transplanting is limiting in large sites and in areas with very vulnerable donor vegetation where mechanical disturbance will incite erosion. 
Future large-scale restoration should employ a mix of different treatments to create a mosaic and to prevent the development of large, homogenous plains.

Cooperation between restoration ecologists, developers, and contractors is essential for the implementation of ecological results into solutions that are technically and logistically feasible in the large-scale restoration, both during planning and the practical work phases. The overall restoration objective of the project was emphasized in the competitive bidding, so contractors were informed when applying for the project. The developer hired a restoration ecologist to follow the project from start to end. A "green seminar" developed by the restoration ecologist in cooperation with the Defense Estate Agency was compulsory to all operating crew (contractors) and included lectures with topics such as restoration ecology, practical experiences with restoration, best and worse practices, and outdoor inspection of the disturbed sites. During the seminar, the contractors and the restoration ecologist set a plan for cooperation during the practical interventions, including a commitment from the restoration ecologist to be available at any time and also to do regular inspections with discussion in the field. These preparations have worked as intended, and there has been a fruitful exchange of scientific, applied, and local knowledge so far during the large-scale restoration, as should be the ideal process in all ecological restoration (Hagen 2003). This type of involvement is known to improve the commitment and endurance of the actors in restoration projects (Reed 2008, Reyes 2011). The green seminar has made all partners conscious of the goals and obligations of the project. The development of a green seminar and the mode of cooperation between the contractors, restoration ecologist, and the developer can be highly recommended for other restoration projects.

Future monitoring data will contribute to improving the sitespecific treatments when it comes to the use of nutrients, the long-term effect of seeding, and how the treatments affect the occurrence and abundance of non-native species. This could involve new ecological recommendations that need to be communicated to contractors. Because of legislation and competitive bidding, new contractors can be expected to enter the project. Repeated green seminars and strong follow-up are needed to keep contractors updated and to accommodate changes in the operating crew.

\section{Adding the ecological targets up to the overall project goal}

The concept of success is complicated when evaluating restoration projects (Zedler 2007). It assumes a precise and measurable goal that success can be valued against, but which is often lacking, and the concept may be used as a subjective value judgment with little scientific relevance (Zedler 2007). Success must also be evaluated at the appropriate temporal scale because the recovery of ecosystems is a slow process and only rarely do monitoring programs run long enough to include the long-term ecological processes (Hughes et al. 2011).

The Defense Estate Agency uses the results and experiences from the pilot project to communicate the large-scale restoration to local people, to politicians, and also internally in the Norwegian Defense. The ecological data are expressed as a scientific guarantee for achieving the overall project goal of the restoration program, also referred to as success (cf. Fig. 1). The large-scale restoration will continue into the next decade, and one obvious challenge will be to prepare the actors and the society to be open to changes in an incorporated procedure if new monitoring data show results that call for new solutions.

Successful ecological restoration projects must contend with the key elements in adaptive management, such as the formulation of overall goals and a limited number of ecological attributes for monitoring, comparative testing of strategies, accepting modification of restoration strategies based on new data, and recognizing local knowledge. We find that the case study described in this paper, the largest restoration project ever approved in Norway, serves as an example of adaptive management and illustrates how impediments of adaptive management can be overcome (Keith et al. 2011). The case study suggests useful procedures for incorporating short-term monitoring data into a long-term restoration and describes cooperation systems between actors that should inspire future restoration projects.

Responses to this article can be read online at: http://www.ecologyandsociety.org/issues/responses. $\mathrm{php} / 5769$

\section{Acknowledgments:}

Thanks to the Norwegian Defense Estate Agency for financing the monitoring program and large-scale restoration and for good cooperation during all parts of the project. Thanks also to the contractors at Hjerkinn for fruitful discussions, to Jan Terje Strømsather for providing data for reference sites, to the field assistants Ellen Torsater Hoff and Tor Ivar Hansen, and to Erik Stange for improving the English language. We also want to thank two anonymous reviewers for useful input to an earlier version of this manuscript.

\section{LITERATURE CITED}

Aradóttir, Á. L. 2007. Restoration of birch and willow woodland on eroded areas. Pages 67-74 in G. Halldorsson, E. S. Oddsdóttir, and O. Eggertsson, editors. Effects of 
afforestation on ecosystems, landscape and rural development. TemaNord 2007:508, Reykholt, Iceland.

Aradóttir, Á. L. 2012. Turf transplants for restoration of alpine vegetation: does size matter? Journal of Applied Ecology 49:439-446. http://dx.doi.org/10.1111/j.1365-2664.2012.02123. $\underline{\mathrm{X}}$

Bates, D., and M. Maechler. 2010. lme4: linear mixed-effect models using S4 classes. $R$ package version 0.999375-33. [online] URL: http://CRAN.R-project.org/package=lme4

Bay, R. F., and J. J. Ebersole. 2006. Success of turf transplants in restoring alpine trails, Colorado, U.S.A. Arctic, Antarctic, and Alpine Research 38:173-178. http://dx.doi.org/10.1657/1523-0430 (2006)38[173:SOTTIR]2.0.CO;2

Bullock, J. M., J. Aronson, A. C. Newton, R. F. Pywell, and J. M. Rey Benayas. 2011. Restoration of ecosystem services and biodiversity: conflicts and opportunities. Trends in Ecology \& Evolution 26:541-549. http://dx.doi.org/10.1016/ j.tree.2011.06.011

Clewell, A. F., and J. Aronson. 2007. Ecological restoration: principles, values and structure of an emerging profession. Island, Washington, D.C., USA.

Comín, F. A., editor. 2010. Ecological restoration: a global challenge. Cambridge University Press, Cambridge, UK.

Conlin, D. B., and J. J. Ebersole. 2001. Restoration of an alpine disturbance: differential success of species in turf transplants, Colorado, U.S.A. Arctic, Antarctic, and Alpine Research 33:340-347. http://dx.doi.org/10.2307/1552241

Crawley, M. J. 2003. Statistical computing: an introduction to data analysis using S-Plus. Wiley, Chichester, UK.

Delach, A., and R. W. Kimmerer. 2002. The effect of Polytrichum piliferum on seed germination and establishment on iron mine tailings in New York. Bryologist 105:249-255. http://dx.doi.org/10.1639/0007-2745(2002)105[0249:TEOPPO] 2.0.CO;2

Den Herder, M., M.-M. Kytöviita, and P. Niemelä. 2003. Growth of reindeer lichens and effects of reindeer grazing on ground cover vegetation in a Scots pine forest and a subarctic heathland in Finnish Lapland. Ecography 26:3-12. http://dx. doi.org/10.1034/j.1600-0587.2003.03211.x

Densmore, R. V. 1992. Succession on an Alaskan tundra disturbance with and without assisted revegetation with grass. Arctic and Alpine Research 24:238-243. http://dx.doi. org/10.2307/1551663

Directorate for Nature Management. 2012. DovrefjellSunndalsfjella nasjonalpark. Enig og tro til Dovre faller. Brochure, Directorate for Nature Management, Trondheim, Norway.
Ebersole, J. J. 2002. Recovery of alpine vegetation on small, denuded plots, Niwot Ridge, Colorado, U.S.A. Arctic, Antarctic, and Alpine Research 34:389-397. http://dx.doi. org/10.2307/1552196

Elmqvist, T., C. Folke, M. Nyström, G. Peterson, J. Bengtsson, B. Walker, and J. Norberg. 2003. Response diversity, ecosystem change, and resilience. Frontiers in Ecology and the Environment 1:488-494. http://dx.doi.org/10.1890/1540-9295 (2003)001[0488:RDECAR]2.0.CO;2

Erschbamer, B., E. Kneringer, and R. N. Schlag. 2001. Seed rain, soil seed bank, seedling recruitment, and survival of seedlings on a glacier foreland in the Central Alps. Flora 196:304-312.

Forbis, T. A. 2003. Seedling demography in an alpine environment. American Journal of Botany 90:1197-1206. http://dx.doi.org/10.3732/ajb.90.8.1197

Gardner, T. 2010. Monitoring forest biodiversity: improving conservation through ecologically responsible management. Earthscan, London, UK.

Grant, C. D. 2006. State-and-transition successional model for bauxite mining rehabilitation in the Jarrah Forest of western Australia. Restoration Ecology 14:28-37. http://dx.doi. org/10.1111/j.1526-100X.2006.00102.x

Gretarsdóttir, J., A. L. Aradóttir, V. Vandvik, E. Heegaard, and H. J. B. Birks. 2004. Long-term effects of reclamation treatments on plant succession in Iceland. Restoration Ecology 12:268-278. http://dx.doi.org/10.1111/j.1061-2971.2004.00371. $\underline{\mathrm{X}}$

Hagen, D. 2003. Assisted recovery of disturbed arctic and alpine vegetation - an integrated approach. Dissertation. Norwegian University of Science and Technology, Trondheim, Norway.

Hildebrand, R. H., A. C. Watts, and A. M. Randle. 2005. The myths of restoration ecology. Ecology and Society 10(1): 19. [online] URL: http://www.ecologyandsociety.org/vol10/iss1/ art19/

Hobbs, R. J., and D. A. Norton. 1996. Towards a conceptual framework for restoration ecology. Restoration Ecology 4:93-110. http://dx.doi.org/10.1111/j.1526-100X.1996.tb00112. $\underline{\mathrm{X}}$

Holl, K. D. 2002. Long-term vegetation recovery on reclaimed coal surface mines in the eastern USA. Journal of Applied Ecology 39:960-970. http://dx.doi.org/10.1046/ j.1365-2664.2002.00767.x

Holling, C. S. 1978. Adaptive environmental assessment and management. John Wiley \& Sons, Chichester, UK. 
Howell, E. A., J. A. Harrington, and S. B. Glass. 2012. Introduction to restoration ecology. Island, Washington, D.C., USA.

Hughes, F. M. R., P. A. Stroh, W. M. Adams, K. J. Kirby, J. O. Mountford, and S. Warrington. 2011. Monitoring and evaluating large-scale, 'open-ended' habitat creation projects: a journey rather than a destination. Journal for Nature Conservation 19:245-253. http://dx.doi.org/10.1016/j.jnc.2011.02.003

Keith, D. A., T. G. Martin, E. McDonald-Madden, and C. Walters. 2011. Uncertainty and adaptive management for biodiversity conservation. Biological Conservation 144:1175-1178. http://dx.doi.org/10.1016/j.biocon.2010.11.022

Kelley, A. M., and H. E. Epstein. 2009. Effects of nitrogen fertilization on plant communities of nonsorted circles in moist nonacidic tundra, Northern Alaska. Arctic, Antarctic, and Alpine Research 41:119-127. http://dx.doi.org/10.1657/1523$\underline{-0430-41.1 .119}$

Krautzer, B., and H. Wittmann. 2006. Restoration of alpine ecosystems. Pages 208-220 in J. Van Andel and J. Aronson, editors. Restoration ecology. Blackwell, Oxford, UK.

MacGillivray, C. W., J. P. Grime, and the Integrated Screening Programme (ISP) Team. 1995. Testing predictions of the resistance and resilience of vegetation subjected to extreme events. Functional Ecology 9:640-649. http://dx.doi. org/10.2307/2390156

Martinsen, O. E., and H. Oskarsen. 2010. Oppformering av sauesvingel - tilbakeføring av Hjerkinn skytefelt til sivile formål [Multiplication of sheep fescue Festuca ovina restoration of Hjerkinn firing range into nature conservation area]. Pages 65-66 in D. Hagen and A. B. Skrindo, editors. Restoration of nature in Norway - a glimpse into the tematic field, professional institutions and ongoing activity. Norwegian Institute for Nature Research, Trondheim, Norway.

Millennium Ecosystem Assessment (MEA). 2005. Ecosystems and human well-being: biodiversity synthesis. World Resources Institute, Washington, D.C., USA.

Ministry of Defence. 1998. Regionalt skyte- og фvingsfelt for Forsvarets avdelinger på Østlandet - Regionfelt $\emptyset$ stlandet. St. meld. nr. 11 (1998-99). White paper, Ministry of Defence, Oslo, Norway. [online] URL: http://www.regjeringen.no/nb/ dep/fd/dok/regpubl/stmeld/19981999/stmeld-nr-11-1998-99-. html?id=192028

Moulton, C. A., and L. Gough. 2011. Effects of soil nutrient availability on the role of sexual reproduction in an Alaskan tundra plant community. Arctic, Antarctic, and Alpine Research 43:612-620. http://dx.doi.org/10.1657/1938-4246-43.4.612
Norwegian Geological Survey. 2011. Bedrock map. Norwegian Geological Survey, Trondheim, Norway. [online] URL: http://geo.ngu.no/kart/berggrunn/

Norwegian Meteorological Institute. 2010. Climate data. Norwegian Meteorological Institute, Oslo, Norway. [online] URL: http://www.eklima.no

Odland, A., and H. K. Munkejord. 2008. The importance of date of snowmelt for the separation of different oligotrophic and mesotrophic mountain vegetation types in Southern Norway. Phytocoenologia 38:3-21. http://dx.doi. org/10.1127/0340-269X/2008/0038-0003

Palmer, M., E. Bernhardt, E. Chornesky, S. Collins, A. Dobson, C. Duke, B. Gold, R. Jacobson, S. Kingsland, R. Kranz, M. Mappin, M. L. Martinez, F. Micheli, J. Morse, M. Pace, M. Pascual, S. Palumbi, O. J. Reichman, A. Simons, A. Townsend, and M. Turner. 2004. Ecology for a crowded planet. Science 304:1251-1252. http://dx.doi.org/10.1126/ science. 1095780

Perrow, M. R., and A. J. Davy, editors. 2002. Handbook of ecological restoration. Cambridge University Press, Cambridge, UK. http://dx.doi.org/10.1017/CBO9780511549984

Pimm, S. L. 1984. The complexity and stability of ecosystems. Nature 307:321-326. http://dx.doi.org/10.1038/307321a0

Pinheiro, J. C., and D. M. Bates. 2000. Mixed-effect models in Sand S-PLUS. Springer, New York, New York, USA. http:// dx.doi.org/10.1007/978-1-4419-0318-1

Pinheiro, J., D. Bates, S. DebRoy, D. Sarkar, and R Development Core Team. 2011. nlme: linear and nonlinear mixed effect models. $R$ package version 3.1-102. [online] URL: http://CRAN.R-project.org/package=nlme

$\mathrm{R}$ Development Core Team. 2011. R: a language and environment for statistical computing. $\mathrm{R}$ Foundation for Statistical Computing, Vienna, Austria.

Reed, M. S. 2008. Stakeholder participation for environmental management: a literature review. Biological Conservation 141:2417-2431. http://dx.doi.org/10.1016/j.biocon.2008.07.014

Rey Benayas, J. M., A. C. Newton, A. Díaz, and J. M. Bullock. 2009. Enhancement of biodiversity and ecosystem services by ecological restoration: a meta-analysis. Science 325:1121-1124. http://dx.doi.org/10.1126/science.1172460

Reyes, J. E. 2011. Public participation and socioecological resilience. Pages 79-92 in D. Egan, E. E. Hjerpe, and J. Abrams, editors. Human dimensions of ecological restoration: integrating science, nature and culture. Island, Washington, D.C., USA. http://dx.doi.org/10.5822/978-1-61091-039-2 6 
Ruiz-Jaen, M. C., and T. M. Aide. 2005a. Restoration success: how is it being measured? Restoration Ecology 13:569-577. http://dx.doi.org/10.1111/j.1526-100X.2005.00072.x

Ruiz-Jaen, M. C., and T. M. Aide. 2005b. Vegetation structure, species diversity, and ecosystem processes as measures of restoration success. Forest Ecology and Management 218:159-173. http://dx.doi.org/10.1016/j.foreco.2005.07.008

Rydgren, K., R. Halvorsen, A. Odland, and G. Skjerdal. 2011. Restoration of alpine spoil heaps: successional rates predict vegetation recovery in 50 years. Ecological Engineering 37:294-301. http://dx.doi.org/10.1016/j.ecoleng.2010.11.022

Skrindo, A., and R. H. Økland. 2002. Effects of fertilization on understorey vegetation in a Norwegian Pinus sylvestris forest. Applied Vegetation Science 5:167-172. http://dx.doi. org/10.1111/j.1654-109X.2002.tb00546.X

Smits, N. A. C., J. H. Willems, and R. Bobbink. 2008. Longterm after-effects of fertilisation on the restoration of calcareous grasslands. Applied Vegetation Science 11:279-286. http://dx.doi.org/10.3170/2008-7-18417

Society for Ecological Restoration (SER). 2004. The SER international primer on ecological restoration. SER International Science \& Policy Working Group. SER, Washington, D.C., USA. [online] URL: http://www.ser.org/ resources/resources-detail-view/ser-international-primer-onecological-restoration

Strømsæther, J. T. 2006. Fra slagmark til nasjonalpark? Undersøkelse av naturlig suksesjon i forstyrrede områder og problemstillinger knyttet til framtidig forvaltning i Hjerkinn skytefelt. Thesis. Norwegian University of Science and Technology, Trondheim, Norway.

Suding, K. N. 2011. Toward an era of restoration in ecology: successes, failures, and opportunities ahead. Annual Review of Ecology, Evolution, and Systematics 42:465-487. http://dx. doi.org/10.1146/annurev-ecolsys-102710-145115

Tischew, S., A. Baasch, M. K. Conrad, and A. Kirmer. 2010. Evaluating restoration success of frequently implemented compensation measures: results and demands for control procedures. Restoration Ecology 18:467-480. http://dx.doi. org/10.1111/j.1526-100X.2008.00462.X

Urbanska, K. M., and J. C. Chambers. 2002. High-elevation ecosystems. Pages 376-400 in M. R. Perrow and A. J. Davy, editors. Handbook of ecological restoration. Volume 2, restoration in practice. Cambridge University Press, Cambridge, UK.

Walker, L. R., and R. del Moral. 2003. Primary succession and ecosystem rehabilitation. Cambridge University Press, Cambridge, UK. http://dx.doi.org/10.1017/CBO9780511615078
Walker, B., A. Kinzig, and J. Langridge. 1999. Plant attribute diversity, resilience, and ecosystem function: the nature and significance of dominant and minor species. Ecosystems 2:95-113. http://dx.doi.org/10.1007/s100219900062

Whisenant, S. G. 1999. Repairing damaged wildlands. Cambridge University Press, Cambridge, UK. http://dx.doi. org/10.1017/CBO9780511612565

Whisenant, S. G. 2002. Terrestrial ecosystems. Pages 83-105 in M. R. Perrow and A. J. Davy, editors. Handbook of ecological restoration. Volume 1, principles of restoration. Cambridge University Press, Cambridge, UK.

Willard, B. E., D. J. Cooper, and B. C. Forbes. 2007. Natural regeneration of alpine tundra vegetation after human trampling: a 42-year data set from Rocky Mountain National Park, Colorado, U.S.A. Arctic, Antarctic, and Alpine Research 39:177-183. http://dx.doi.org/10.1657/1523-0430(2007)39 [177:NROATV]2.0.CO;2

Young, T. P., D. A. Petersen, and J. J. Clary. 2005. The ecology of restoration: historical links, emerging issues and unexplored realms. Ecology Letters 8:662-673. http://dx.doi.org/10.1111/ j.1461-0248.2005.00764.x

Zedler, J. B. 2007. Success: an unclear, subjective descriptor of restoration outcomes. Ecological Restoration 25:162-168. http://dx.doi.org/10.3368/er.25.3.162 